\title{
A data símbolo de 1898: o impacto da independência de Cuba na Espanha e Hispanoamérica ${ }^{1}$
}

Maria Helena Rolim CAPELATO²

RESUMO: O artigo tem como objetivo analisar o impacto da Independência de Cuba nos intelectuais espanhóis e hispanoamericanos e as razões da aproximação entre eles após o evento. 1898 tornou-se uma datasímbolo pelas mudanças significativas que produziu nas concepções de escritores hispânicos sobre o papel dos Estados Unidos na América Latina e sobre o destino da Espanha após a perda de sua última colônia.

PALAVRAS-CHAVE: História intelectual; hispanidade; independência de Cuba.

1898 tornou-se uma data-símbolo na historiografia espanhola, vista como um marco de mudanças importantes na Espanha e América Hispânica. Mas este, como todo e qualquer marco histórico, está sujeito a uma infinidade de interpretações, que comportam inclusive a relativização de sua importância.

O tema tem sido exaustivamente estudado. Carlos Blanco Aguinaga refere-se à grande quantidade de livros e artigos publicados sobre 98 no ano do seu centenário; eles foram escritos tanto por especialistas como por periodistas. Além disso foram realizadas inúmeras conferências e congressos a propósito do que os espanhóis de 98 chamaram de o "Desastre", com D maiúsculo. ${ }^{3}$

Em 1989, foi organizado um Encontro Internacional na UNAM (Universidad Autonoma de México) com o intuito de comemorar o Primeiro Centenário da chamada "geração de 98". Com a participação de especialistas espanhóis e hispano-americanos, o assunto foi debatido 
sob diversos ângulos e resultou em algumas publicações que fazem parte da Coleção "Latinoamérica fin de Milenio". Dois títulos foram dedicados especialmente ao tema: 98: derróta Pírrica e El 98 y su impacto en Latinoamérica. No prólogo de um deles afirma-se que, em se tratando do encontro de dois mundos, 1492 foi o primeiro e o de maior transcendência. Depois desse acontecimento, o mais destacado é o do ano axial de 1898, muito significativo para a história dos povos hispânicos.

Em 1898 os Estados Unidos emergiram como grande potência, e um século depois ainda se mantinham como tal, alcançando uma hegemonia unipolar. Seu primeiro feito de destaque foi a derrubada dos últimos bastiões espanhóis na América (Cuba e Porto Rico) e na Ásia (Filipinas). Mas 98 não representou unicamente uma grande vitória da nova potência imperialista — os EUA —, mas o fim do decadente colonialismo espanhol.

O episódio teve muitos desdobramentos e foi alvo de múltiplas interpretações. Pretendo abordar alguns dos significados desse acontecimento, levando em conta o que ele representou, não só para os espanhóis, mas também para os hispano-americanos.

Cabe, de início, enfatizar a mudança que 98 produziu nos olhares recíprocos, dando origem à construção do conceito de hispanidad, pleno de significado ideológico.

O "Desastre" teve impacto muito negativo para os políticos espanhóis e para as camadas mais conservadoras da sociedade, que o sentiram como uma "mancha na honra militar".

Os debates da época acusam ampla e rica discussão em torno do problema. Azorín, um dos intelectuais identificados com o grupo denominado "geração de 98", escreveu no jornal $A B C$, em 1913, que eles tinham sido estimulados pela experiência do "Desastre". O acontecimento avivou as críticas e radicalizou as posições dos intelectuais.

É preciso deixar claro que, neste texto, não estou me propondo a fazer uma recuperação da história da Espanha no período. A ênfase da análise será posta na atuação de um conjunto de intelectuais que, motivados por preocupações e busca de soluções para os problemas de seu tempo, passaram a refletir sobre questões de natureza individual, social e política. 
Tomando como referências básicas os temas da modernidade/modernização/modernismo (final do século XIX e início do século XX), que suscitaram uma polêmica em torno do que significava "ser nacional", pretendo mostrar em que medida a construção do marco de 98, envolvendo Espanha e hispano-América, contribuiu para a afirmação de uma intelectualidade mais integrada e participante em relação às questões de sua época.

A chamada geração de 98 manifestava angústia pelo estado de decadência a que estava submetida a Espanha. Os autores procuravam analisar as causas desse mal e propunham soluções para regenerar o país; por esse motivo são identificados também como "regeneracionistas". Caracterizavam-se por uma percepção negativa da nação espanhola e lamentavam o fato do país manter-se à margem da Europa. Definiam a Espanha como um país rural, marcado por graves problemas econômicos e políticos. Criticavam o sistema político, controlado por "caciques" (só votava certa de $4.5 \%$ a $5.5 \%$ da população) que resolviam os conflitos sociais e políticos através da censura e da repressão policial. Condenavam, também, a forte presença religiosa e militar no governo e o descaso com a educação. Alegavam que a maioria das crianças não ia à escola, e o ensino primário, secundário e universitário era de baixa qualidade e estava, em sua grande maioria, nas mãos da Igreja.

Consideravam que, embora a Espanha tivesse dado início a um processo de modernização econômica, as condições materiais eram ainda muito precárias. O escritor Ramiro Maeztu, após sua visita a Cuba em 1891, afirmou que a ilha era, em muitos aspectos, mais avançada que a metrópole, pois ao longo do século havia passado por transformações importantes que deram forte impulso aos negócios. ${ }^{4}$

Outra fonte de insatisfação na época era o serviço militar obrigatório - só para os pobres - , pois quem podia pagar pela isenção se livrava dele; o Estado permitia que se designasse um substituto. $\mathrm{Na}$ guerra de Cuba, a ida dos jovens pobres causou indignação entre as classes populares. A geração de 98 era anticlerical e antimilitarista.

A derrota na guerra de Cuba foi responsável por uma crise de identidade que se integrou numa crise mais ampla, de âmbito europeu, caracterizada por reações contra a modernidade e a modernização. 
A revisão de valores que se manifestou na sociedade européia foi produzida por importantes mudanças econômicas e sociais relacionadas ao processo de industrialização, de urbanização acelerada e emergência de conflitos entre burguesia e operariado. Nesse contexto de amplas mudanças, no qual a Espanha se inseria ainda que de forma moderada, a nação ibérica se viu atingida pela guerra de Independência de Cuba. As repercussões da derrota não podem deixar de ser levadas em conta para se compreender os problemas que preocuparam os intelectuais espanhóis nesse final do século.

$\mathrm{Na}$ introdução do livro Fuera del Olvido: los escritores hispanoamericanos frente a 1898, Lourdes Royano afirma que o ano de 1898 constitui uma data paradigmática para a cultura espanhola e hispanoamericana. Para a autora, o "Desastre" resultante da guerra de Independência de Cuba não foi vivido apenas como uma derrota militar que trouxe consigo a perda das últimas colônias de ultramar. Tampouco significou a independência definitiva de um continente em relação à sua antiga metrópole. Mais do que isso, 1898 representou um momento conjuntural dentro do mundo hispânico que deu lugar a um diálogo enriquecedor entre escritores de uma e outra margem do Atlântico. Em sua grande maioria, os intelectuais do final do século XIX questionaram os valores de uma cultura expansiva — a anglo-saxã — cuja impetuosa modernidade se impôs sobre a tradição humanista da cultura latina que esteve na base da cultura ibérica. ${ }^{5}$ A discussão que se travou em torno da cultura saxã versus cultura latina serviu para unir espanhóis e hispano-americanos. Como afirma Royano, a literatura produzida por eles, nessa época, foi fundamental para a evolução literária do século XX. Os grandes escritores espanhóis e hispano-americanos se converteram em modelos internacionais.

Tratarei, num primeiro momento, de caracterizar o que foi a geração de 98 e o que representou sua produção cultural. A seguir, procurarei me deter na relação entre intelectuais espanhóis e hispano-americanos, procurando mostrar como se deu a inversão dos olhares recíprocos e como se constituiu o conceito de hispanidad. No final, apresentarei uma reflexão sobre as posições políticas dos representan- 
tes de 98, indicando mudanças que ocorreram ao longo de suas trajetórias de vida.

\section{A GERAÇÃO DE 98: REGENERACIONISTAS E MODERNISTAS}

Luis de Lhera, no texto intitulado Historiografia y modernismo literário, afirma que a geração de 98 teve duas origens muito diferentes. A primeira se relaciona ao momento político da derrota na guerra de Independência de Cuba, quando se realizou o acordo com os EUA, ocasionando a perda de Cuba, Porto Rico, e mais tarde Filipinas. A segunda está relacionada ao surgimento da palavra intelectual posta em moda na Europa, França e Espanha principalmente, quando, no final do século XIX, homens de ciência e cultura passaram a intervir no debate público através da publicação de manifestos e presença forte na imprensa. Nessa época, os problemas relativos à Restauração espanhola provocaram, no ambiente intelectual, reação dos autores à política $\mathrm{e}$ instituições nacionais. Manifestaram falta de confiança no sistema parlamentar, criticaram os militares e membros do clero, protestaram contra a ineficiência do governo perante a sociedade corrompida por interesses burgueses. Nesse contexto, os intelectuais tomaram para si a incumbência de regenerar o país, atitude que os colocava na posição de guardiões críticos do Estado e da sociedade espanhola. A atuação deste setor produziu na sociedade um novo poder que atuava através da imprensa e opinião pública. Arvoraram-se em superego da nação e agiram como sábios ou juízes da coisa pública. Revelaram, nos primeiros tempos, uma tendência progressista ante dos conservadores (Clero e Forças Armadas) e se manifestaram a favor da secularização do ensino e da vida pública.

A propósito do conceito de geração, Luís Lhera relata que Azorín apropriou-se deste termo, que fora cunhado pelo então jovem escritor Ortega y Gasset, para descrever o grupo de intelectuais do qual fazia parte, e utilizou, em 1913, a expressão: "nós, os da geração de 98". Javier Pinedo aceita o conceito e define esse grupo de jovens intelectuais como "geração de 98", a partir de alguns critérios. Além da proximida- 
de de nascimento, da formação educacional concomitante e similar, dos contatos muito freqüentes nos salões e cafés principalmente, foram marcados por acontecimentos históricos importantes como a derrota na guerra de 98. Do ponto de vista literário, recusavam os cânones da geração anterior, a do realismo literário, e usavam uma linguagem comum, que na maioria deles correspondia ao modernismo. Discussões estéticas e literárias, políticas e sociais criaram um marco de referências novas para interpretar a Espanha. O pessimismo crítico, as preocupações com o futuro do país e a conseqüente ênfase na necessidade de regeneração foram predominantes. O resultado foi uma mudança profunda na literatura e nas artes espanholas e uma nova visão da Espanha e de seu significado histórico. ${ }^{6}$

Pedro Cerezo Galán, ao abordar a "dupla crise ideológica e intelectual do 98", destaca o surgimento de uma nova sensibilidade de amplo horizonte histórico, que se poderia designar "espírito do tempo", categoria que considera mais apta que a de geração para caracterizar o grupo que sofreu uma mutação relevante de consciência. A crise não era só espanhola, mas européia, e tinha no industrialismo o seu fundamento. A revisão de crenças e valores foi, segundo o autor, decorrente de mudanças mais profundas que resultaram num mal-estar da cultura. $^{7}$

O duplo aspecto da crise manifestou-se na posição dos escritores de 98. Azorín se ateve à situação espanhola que provocara um "grito de rebeldia, desdém em relação ao caduco, indignação frente ao oficial". Pio Baroja privilegiou a tendência cultural mais profunda, o espírito do tempo, caracterizado pelo individualismo, injustiça social, desprezo pela política, pelo anarquismo e pelo misticismo. Neste caso, o problema da Espanha era um problema europeu.

A obra de Miguel de Unamuno, En torno al casticismo, resultado de um conjunto de ensaios escritos em 1895, mostra que a crise era anterior ao "Desastre", que só veio a torná-la mais evidente. Menendez y Pelayo, embora não mencionado por respeito ao antigo mestre, era considerado pelo autor como o protótipo do intelectual castiço, disposto a guardar as essências da Pátria de toda contaminação estranha. Unamuno se propôs a mover-se fora da antinomia entre tradição e pro- 
gressismo, propondo uma síntese entre as duas tendências. Ángel Ganivet, em correspondência pública com Unamuno, também apontou para a necessidade de superação integradora das forças em litígio. Ramiro de Maeztu considerava que o problema da Espanha era o dogmatismo que significava uma afirmação integral da tradição, resultando numa atitude integrista própria da Espanha da Contra-Unamuno, argumentando que a europeização da Espanha fora eloqüente mas superficial pois, no fundo dela, permanecera um sentido religioso da vida, essencialmente hispânico. Ressaltava ser necessário superar a tradição histórica e romper com o castiço temporal. A tradição castiça de base religiosa e teológica, simbolizada pela cruz e espada, produzira o controle religioso da consciência e dominação política a serviço do unitarismo. A Inquisição significara a "aduana do utilitarismo castiço", responsável pelo antimoderno e pelo integrismo. Estas teriam sido as conseqüências de se estabelecer a religião como vínculo social e forma de unidade política. Diante de tão profundo problema, propunha a realização de uma superação da personalidade castiça cristalizada através de vários séculos de monarquia católica. A mudança profunda dizia respeito à transformação do "caráter espanhol", imprescindível para a regeneração do país.

Nem reforma nem revolução bastariam, era necessário que na consciência coletiva do povo se produzisse uma crise tal, capaz de provocar a cura da personalidade patológica. A solução, de fundo psicanalítico, pressupunha acabar com o velho eu para que, de suas ruínas e nutrido delas, surgisse um novo eu.

Unamundo e Maetzu tinham a mesma percepção sobre os resultados de 98: a crise tocara fundo mas não provocara a renovação desejada. O regime canovista resistira intacto a ela. Unamuno, perante a indiferença da população, passou a manifestar frustração com os resultados do "Desastre", que não produzira nenhuma mudança política. Passou a preocupar-se com o marasmo da Espanha, referindo-se ao estado de abulia, ao mal endêmico do caráter espanhol. Como o mal era profundo, voltou-se, junto com seus companheiros, para a tarefa de regeneração. Como não se produzira a revolução desde arriba, nem desde abajo, a alternativa era batalhar pela revolução na raíz. 
O impacto da crise do fim do século e a preocupação com os males da Espanha uniram os intelectuais espanhóis da época no desejo de regenerar a nação através da sua incorporação à modernidade, sem perder as bases de sua identidade. A Espanha, como pátria, como realidade histórico-cultural, como convergência de valores espirituais, guiou os propósitos regeneracionistas. Mas eles também se preocuparam com a regeneração da Espanha dos pontos de vista político, econômico e social.

O termo regeneração, geralmente associado a condições materiais e sociais/raciais era muito difundido no Ocidente, tanto na Europa como na América. Os "regeneradores" de 98 preocupavam-se com as condições materiais (econômicas, sociais e políticas) do país, mas estiveram, acima de tudo, empenhados na regeneração espiritual da raça hispânica; a raça, neste caso, era entendida no sentido cultural.

A "geração de 98" delineou um projeto moderno sem abandonar as bases da hispanidad. Pinedo se refere a esse projeto de identidade e modernidade espanhola como "ser outro sem deixar de ser o mesmo". Esses intelectuais foram responsáveis por uma explosão literária que expressava a desolação nacional causada pelo "Desastre colonial”.

Luis Lhera considera que há diferenças entre a "geração de 98 " e os "modernistas". Os primeiros se caracterizaram pela preocupação com temáticas regeneracionistas e os segundos, literatos puros, preocuparamse com a renovação do estilo. A linha divisória entre eles não é muito nítida. Citando Federico de Onís, refere-se ao modernismo como uma forma hispânica de manifestação da crise universal das letras e do espírito, ocorrida a partir de 1885, com manifestações na arte, ciência, religião, política, tendo como fundamento mudanças históricas.

Apesar das diferenças, Lhera considera que modernismo e geração de 98 se cruzaram e revelaram influências mútuas. Ambos se identificaram com movimentos de reforma. A posição intelectual da "geração de 98" diante da história e da vida espanhola produziram um movimento político e literário nacionalista no sentido de interpretação da realidade nacional; mas aceitaram também as reformas estéticas, literárias, de caráter cosmopolita. 
Dentre os nomes da "geração de 98", Azorín destaca, além dele mesmo, Miguel Unamuno, Pio Baroja, Ramiro de Maeztu, Valle Inclan, Benavente, Rubén Darío. Dentre os modernistas são mencionados Valle Inclan, Benavente e Rubén Darío. Outros autores acrescentam os nomes do poeta Antonio Machado (como expressão do modernismo literário), de Menendez Pidal (como regeneracionista, embora pertencesse a uma geração anterior), além de Ángel Ganivet, Ricardo Macías Picavea, Joaquín Costa, Rafael Altamira e Luis Morote.

Todos se caracterizaram, em maior ou menor grau, pelo protesto moral, pela rebeldia, pela crítica social, e foram responsáveis por um renascimento literário.

Adolfo Sánchez Vazquéz menciona especificidades dos autores: alguns, como Unamuno, Maeztu e Azorín, eram mais preocupados com problemas políticos, e outros, Pio Baroja, Antonio Machado e Valle Inclan, mais voltados para questões literárias. ${ }^{8}$

Pedro Ribas menciona algumas características da interpretação da Espanha realizada pelo grupo. Menciona a descoberta de Castilha (feita por autores de outras regiões), a indagação e análise sobre os traços do caráter espanhol, e também a interpretação nova da história da Espanha. ${ }^{9}$

As propostas para a solução da crise interna, de caráter profundo, criaram polêmicas entre os "regeneracionistas" e sofreram alterações ao longo do tempo. Unamuno propunha que, diante do marasmo, do pântano de água estagnada e da falta de correntes vivas internas, a solução era abrir as fronteiras da Espanha e permitir que chegassem à península ares da modernização dos vizinhos: era favorável à europeização da Espanha. Mas a partir de 1905, quando foi acometido por uma crise existencial que o fez voltar-se para a metafísica, passou a recusar as soluções concretas e a enfatizar a solução espiritual; a partir de então, a europeização da Espanha perdeu sentido para ele . Maeztu, na obra Hacia otra España (1899), também propôs a europeização da Espanha. Tomando como exemplos a modernização e o progresso material da Inglaterra, Alemanha e França, deu ênfase à necessidade de soluções concretas para os problemas da Espanha. Chegou a atacar 
Unamuno quando se tornou metafísico e criticou Ganivet pelo idealismo mas, a partir de 1911, após uma viagem à Alemanha, mudou radicalmente: aproximou-se ideologicamente dos autores que antes criticara e suas posições passaram a se caracterizar pelo subjetivismo e espiritualismo. Passou a questionar a modernidade, acusada de economicista e vulgar, alheia às expectativas espirituais. A ânsia de dinheiro, afirmou o autor, era insuficiente para fazer uma nação recobrar a iniciativa histórica. Acabou cerrando fileiras com os católicos integristas.

Por fim, a proposta identitária para a regeneração da Espanha prevaleceu sobre as soluções concretas, voltadas para a modernização de estilo europeu.

As obras mais representativas do 98 estavam impregnadas de pessimismo, e algumas delas representaram verdadeiras metáforas de uma Espanha carente de vontade política e reservas morais.

A "geração de 98" caracterizou-se, acima de tudo, por uma reflexão sobre a "alma" da Espanha e sobre o significado do país na história. Ganivet identificava a Espanha com a moral cristã, espírito de independência, individualismo indisciplinado e genialidade improvisadora; Unamuno, com o espírito castelhano. Ambos assumiam a idéia de decadência e esgotamento do país, acreditando que ele vivia, no final do século XIX, uma gravíssima crise histórica, e consideravam que só a recuperação da verdadeira essência nacional permitiria sua sobrevivência como nação.

A Espanha representava, pois, um problema, uma preocupação e um fracasso em termos de nacionalidade. A visão de uma "Espanha negra" estava em muitos outros textos.

Castilha era, na perspectiva desses autores, a essência mesma da nacionalidade espanhola: uma Castilha quixotesca, na concepção que Unamuno e Azorín tinham de Don Quixote; uma Castilha de paisagens desoladas e frias, tristes e nobres, campos vazios e cidades decrépitas, na poesia de Machado; uma Castilha realista, na concepção dos outros autores.

A herança de 98 foi, pois, uma reflexão ensimesmada sobre a idéia de Espanha e sua realidade histórica, como já mencionei. As manifes- 
tações dos autores foram, desde o início, polêmicas. Eles se criticavam entre si, seja pelo pessimismo exacerbado, seja pelo diletantismo "estrangeirizante", seja pelo desdém à tradição ou pela invenção de uma Espanha sombria e arruinada. A esquerda os questionava por não terem entendido que o problema da Espanha era antes de tudo um problema político, uma questão de democracia.

\section{ESPANHA E AMÉRICA HISPÂNICA NO CONTEXTO DE 98}

O hispano-americanismo, cujos primeiros impulsos partiram de liberais com Rafael Altamira, serviu para o restabelecimento das relações culturais entre os países, reintroduzindo a América como fator necessário à política espanhola. Abriu, ainda que timidamente, o mercado americano a alguns escritores espanhóis: Unamuno, Grandmontagne e Salaverria residiram por alguns anos na América, estabelecendo contatos importantes e produzindo livros interessantes. A presença de Ortega y Gasset em Buenos Aires, a partir de 1916, foi extremamente produtiva para o pensamento argentino.

Mas o encontro entre Espanha e América hispânica teve também seu lado mais questionável. Interesses políticos e ideológicos resultaram na produção de um discurso de exaltação nacionalista que, já em 1918, quando se celebrou o 12 de outubro como festa da "raza" hispânica pela primeira vez, apresentou a hispanidad como comunidade espiritual entre Espanha e América. A idéia de hispanidad serviu de justificativa para projetos antidemocráticos e orientou a formação de grupos nacionalistas de extrema direita dos dois lados do Atlântico.

O 98, como exame de consciência nacional, impulsionou o "redescobrimento" da América espanhola e de seus vínculos com a cultura nacional. O reencontro das duas culturas acabou sendo denominado de hispano-americanismo.

Teodósio Fernández escreveu um artigo importante sobre a relação entre hispânicos dos dois mundos. Lembra que as décadas finais do século XIX foram marcadas pelo predomínio das potências capita- 
listas da Europa e América (EUA) e pela expansão imperialista. A Espanha não figurava entre elas e a hispano-América foi alvo da política de domínio externo. A atuação dos norte-americanos na guerra de $\mathrm{Cu}$ ba acabou provocando reação não só na Espanha mas nos países americanos. 98, o ano da derrota espanhola, acabou adquirindo um marco histórico para as duas culturas porque tornou possível uma nova unidade dos países hispânicos conjuntamente marginais ante a presença do imperialismo moderno no mundo. Portanto, concluiu o autor, essa data é tanto espanhola como americana. Afinal, a derrota foi compartilhada por espanhóis e hispânicos da América em virtude do poderio dos Estados Unidos, convertido numa ameaça que os anos posteriores confirmariam. ${ }^{10}$

Entre os intelectuais americanos, os protestos contra as intervenções em Cuba não tardaram a surgir. O colombiano José Maria Vargas Vila escreveu Ante los bárbaros em 1903, onde relembrou que eles (norte-americanos) invadiram o México, aprisionaram Cuba, Haiti e Santo Domingo, conquistaram Porto Rico, despedaçaram a Colômbia e roubaram o Panamá. O argentino Manuel Ugarte em El porvenir de la América española (1910), e em muitos outros escritos, considerou que os males das nações latino-americanas derivavam da fragmentação e vassalagem colonial e semi-colonial imposta pelas potências imperialistas.

No final do século XIX teve lugar, tanto na Europa como na América, uma ampla polêmica entre saxonismo e latinismo. Autores como Gustave Le Bom, em Leyes psicológicas de la evolución de los pueblos (1894), Edmond Demolins, na obra En que consiste la superioridad de los anglosajones (1897), e muitos outros, procuravam ressaltar a superioridade dos anglo-saxões em relação aos povos latinos. A vitória norte-americana sobre a Espanha confirmava essas teses.

$\mathrm{Na}$ América hispânica, muitos autores, que procuraram interpretar as causas do atraso dos seus países, utilizaram essa tese. $\mathrm{O}$ argentino Carlos Octávio Buñes, em Nuestra América (1903), denunciou os defeitos das raças hispânica e indígena: preguiça, tristeza e arrogância constituíam, para o autor, os traços próprios do caráter das raças inferiores.

Mas os intelectuais que estiveram na Espanha ou mantiveram con- 
tato com os regeneracionistas foram atraídos por suas inquietações renovadoras. Identificaram-se com os povos que enfrentavam problemas semelhantes aos seus (pobreza do solo, atraso econômico, deficiências administrativas e partidárias, defeitos do caráter nacional) e esboçavam projetos para solucioná-los. Os acontecimentos de 98 facilitaram a aproximação entre os reformadores de um lado e outro do Atlântico, decididos a superar as deficiências e lutar pelo progresso de suas respectivas nações.

Em época anterior, muitos intelectuais e políticos haviam proposto a americanização da América hispânica como forma de superar o "atraso", mas as agressões norte-americanas da segunda metade do séc XIX foram produzindo, pouco a pouco, uma inversão de valores que acabou provocando um sentimento pró-latinidade, aí incluindo os franceses e espanhóis. A valorização da tradição latina veio acompanhada da construção de uma imagem negativa dos EUA. Modernistas franceses, como Jean Marie Guyau, identificaram as grosseiras correntes materialistas do século com o "americanismo", e Ernest Renan criou, para caracterizá-las, o símbolo de Calibán. O termo não tardou a difundir-se. Rubén Darío, em visita a Nova York, em 1893, afirmara que Calibán reinava na ilha de Manhattan, em São Francisco, em Boston, em Washington, em todo o país. O franco-argentino Paul Groussac e o argentino Roque Sáenz Peña criticaram “a agressão do yanquee contra la hidalga y hoy agobiada España”.

Mas Darío era o mais veemente. Em 1898 escreveu um breve texto "El triunfo de Calibán”, no qual caracteriza os estadunidenses como "bárbaros, comedores de carne crua, cíclopes, bestiais, grosseiros que vão por suas ruas empurrando-se e roçando-se de forma animalesca, à caça do dólar". "Não posso, nem quero estar perto desses búfalos de dente de prata, são inimigos meus, são os que aborrecem o sangue latino."

O poeta que foi pouco a pouco deslizando do saxonismo para o latinismo, radicalizou suas posições em 98. No diário La Nación, de Buenos Aires, do qual foi correspondente na Espanha a partir do final de 1898, escreveu sua primeira crônica demostrando esse sentimento de solidariedade em relação ao vencido que surgiu após a derrota de 98: 
De novo em marcha, em direção ao país materno que a alma americana - americano-espanhola — há de saudar sempre com respeito, há de querer com carinho profundo. Porque se já não é a antiga poderosa, a dominadora imperial, cabe amá-la em dobro; e se está ferida, estende a mão a ela muito mais. ${ }^{11}$

Do encontro de Rubén Dario com Unamuno surgiu o par que se destacou pela constituição de uma rede de contatos, correspondências, comentários e circulação de obras e pessoas interessadas pelo ibérico e o americano no começo do século. Nesses anos viajaram ou se instalaram na Espanha numerosos intelectuais latino-americanos, e espanhóis vieram para a América Latina onde permaneceram por algum tempo. Maeztu e Baroja escreveram textos sobre este continente; Unamuno destacou o parentesco maior da Espanha com a América hispânica e salientou a vantagem de uma aproximação espiritual entre os povos de língua castelhana. Rafael Altamira, que também se destacou pela preocupação com a América, foi inspirador de política culturais visando a maior contato entre esses dois mundos. Enfatizou a necessidade de fazer crescer o prestígio espanhol entre os povos americanos de origem hispânica e convencê-los da importância de conviverem espiritualmente. ${ }^{12}$

Rubén Darío, quando sediado na Argentina, propôs a unidade dos latinos contra o inimigo comum - os Estados Unidos. Afirmou que apesar de ter-se declarado pela Cuba livre, acompanhando-a em seu sonho, tornou-se amigo da Espanha no momento em que a viu agredida por um inimigo brutal, que fez uso da violência, da força e da injustiça. ${ }^{13}$

Naquele momento, a Espanha, filha de Roma e irmã da França, passou a ser vista como parte de uma verdadeira tradição ibero-americana: a tradição latina. Muitos outros adotaram a defesa da latinidade. Vargas Vila escreveu que as possibilidades de sobrevivência dos países latino-americanos estavam relacionadas com sua capacidade de conseguir a união com a "Mãe Pátria" e a aproximação com a "Itália e a França, as filhas mais velhas da raça. Neste caso, a palavra raça não tinha uma conotação étnica pois estava relacionada a civilização e ideais 
compartidos. Foi nessa atmosfera que se gestou Ariel, obra publicada em 1900. ${ }^{14} \mathrm{O}$ uruguaio José Antonio Rodó levou mais longe a contraposição entre anglo-saxões e latinos.

Nesse livro Rodó reiterou a visão dos Estados Unidos como reino de Calibán, onde o utilitarismo havia afetado negativamente os valores espirituais e morais e, através da figura de Ariel, procurou recuperar a latinidade. Assim se concretizava uma nova mensagem regeneracionista, destinada a enfrentar os perigos de um tempo de decadência, fruto do bestial materialismo do fim do século. Durante mais de duas décadas o arielismo constituiu uma espécie de "evangelho latino-americano", citado e seguido por inúmeros escritores. Transformando-se em corrente de pensamento, contribuiu para consolidar as esperanças na raça latina, associada ao idealismo e contrária ao mercantilismo utilitário dos EUA, definido por Rodó como "nordomania" que afetava muitos intelectuais latino-americanos.

Na Argentina, o centenário da Revolução de Maio de 1810(momento da primeira declaração de Independência) deu ensejo a reflexões em torno das origens nacionais. Nessa época, havia uma nova geração de escritores que se mostrou preocupada com a possibilidade de perda da identidade nacional devido à entrada maciça de imigrantes estrangeiros. Diante do "crisol de razas", as raízes hispânicas foram recuperadas. A primeira corrente de pensamento nacionalista, que se firmou no país no início do século XX, tinha afinidades com os regeneracionistas espanhóis. A herança espanhola assumia uma significação nacionalista ao integrar-se na busca de identidade própria, perdida no passado indígena e colonial, mas considerada ainda viva na atmosfera tradicional das províncias menos afetadas pela imigração e pela modernização corruptora. Os autores procuraram recuperar a Argentina verdadeira e eterna para com ela fazer frente aos perigos e inseguranças acarretados pelas transformações da época.

Escritores como Ricardo Rojas e Manuel Gálvez tornaram-se representativos desse momento. Eles aprofundaram as críticas ao projeto liberal oligárquico que servira de base à construção da Argentina moderna. Gálvez exaltou a tradição hispânica, vista como base da ar- 
gentinização do país. Na alma da raça e na antiga grandeza espiritual, a nação encontraria recursos para abordar a espiritualização da consciência nacional como remédio contra o materialismo que imperava no país. Ricardo Rojas também se opôs ao materialismo e propôs o estudo da história para fomentar o nacionalismo; para o autor, a nacionalidade representava a consciência de uma personalidade coletiva.

Os nacionalistas argentinos desse período formavam um grupo que, segundo Gálvez, exercia uma missão semelhante à que teve na Espanha a geração de ideólogos surgida depois do "Desastre". Como decorrência desse intercâmbio de idéias, segundo Fernandez, os hispano-americanos passaram a ver seus países como um problema, sobretudo moral, segundo Maeztu. Também se sentiram estimulados a desprender-se das matrizes de pensamento positivista-cientificista para interpretar a realidade nacional e trabalhar pela reconquista dos valores espirituais perdidos, distanciando-se dos interesses materiais. Os autores dessa época dialogaram com os espanhóis e com os ideólogos da nova direita nacionalista francesa: Charles Maurras, Maurice Barrès e outros. ${ }^{15}$

A mudança de visão da Espanha com relação à América e viceversa se deu a partir de acontecimentos ocorridos nesses dois mundos: no que se refere ao mundo espanhol, é preciso levar em conta que a atuação conjunta de intelectuais hispano-americanos, como Rubén Darío, com os espanhóis no projeto regenerador foi muito importante; no mundo americano, há que ser considerar que a chegada de inúmeros imigrantes espanhóis na América, a partir da segunda metade do século XIX, alterou a visão que os americanos tinham do poder da metrópole e de seus filhos colonizadores. O intercâmbio intelectual aproximou espanhóis e hispano-americanos. Além disso, a animosidade contra os EUA era um denominador comum.

A presença dos norte-americanos na América Latina desde a independência de Cuba teve importância no despertar da simpatia pela Espanha nas repúblicas hispano-americanas.

Segundo Eduardo Devés, a emergência dos EUA como país expansionista e imperialista deu origem a teses identitárias que reconhe- 
ciam no latino, em geral, e no hispano, em particular, um componente real e legítimo do que era a "nossa América". Lembra que, para Darío, tanto quanto para Rodó, o latino estava marcado pelo signo da cultura, da civilização e do espírito, elementos que "todos levamos dentro de nós e que nos pertence".

$\mathrm{O}$ autor procurou mostrar que os contatos dos latino-americanos com a Espanha no plano intelectual foram configurando uma rede de solidariedade na qual americanos e peninsulares teceram laços identitários a partir de idéias e sensibilidades comuns. Para Devés, essa solidariedade que significa imaginar ou reimaginar uma identidade, mesmo que seja parcial, só é possível a partir da definição de um inimigo comum. Nesse sentido, o latinismo e o iberismo só se configuraram como tais na medida em que passaram a identificar o saxão como um inimigo e, às vezes, até como um bárbaro ou como um inferior. ${ }^{16}$

Não se pode afirmar que essa visão identitária dos regeneracionistas fosse plenamente progressista e democrática, mas enquanto os debates permaneceram no plano da cultura e da mentalidade, as críticas à situação vigente, controlada pelos conservadores, foram freqüentes. Porém, com o passar do tempo, diante do recrudescimento dos conflitos sociais e políticos e da evolução do quadro europeu no sentido de uma radicalização entre esquerda e direita, os regeneracionistas tanto da Europa como da América foram se definindo ideologicamente no sentido da extrema direita. Poucos permaneceram no quadro do liberalismo político. É o que pretendo mostrar a seguir.

\section{A GERAÇÃO DE 98 E A POLÍTICA}

A "geração de 98" tentou aproximar a Espanha da modernidade, ou seja, da razão, da democracia, do progresso econômico. Mas, num segundo momento, seus integrantes chegaram à conclusão de que a verdadeira salvação estava na afirmação da identidade espanhola e se propuseram a resgatar a hispanidad.

Esses intelectuais viveram um período de crise global. Enquanto 
jovens, conviveram com as idéias de Marx, Spencer, Nietzche, Schopenhauer, aproximaram-se dos anarquistas, dos socialistas, mas acabaram por se tornar conservadores indo ao encontro de soluções pessoais, no plano da metafísica, ou políticas, junto aos setores da extrema direita. Na juventude, lutaram pela abertura da sociedade espanhola, mas na maturidade, a maioria optou pelo refúgio no passado hispânico. O projeto regenerador transformou-se num assunto de identidade nacional.

O "Desastre" produziu uma catarse coletiva que permitiu gerar a idéia de ressurreição da Espanha. O pessimismo e visão crítica iniciais resultaram numa explícita atitude de denúncia política e social. Alguns membros de "98" chegaram a se identificar, por um certo tempo, com as correntes de esquerda. Unamuno militou em agremiação socialista e escreveu artigos influenciados pelo marxismo no semanário "La lucha de Clases"; em sua trilogia intitulada La lucha por la vida (La lucha, Mala yerba, Aurora Roja). Baroja romanceou o baixo mundo de Madri, os bairros e as classes marginais e o anarquismo. Azorín denunciou a fome e a greve em Andaluzia em artigos escritos em 1905. É importante lembrar que o anarquismo era forte na Espanha dessa época, sobretudo na Catalunha.

A "geração de 98" demonstrava grande descontentamento em relação à política oficial. Galdós, autor da geração anterior, mas também crítico da política Restauradora, escreveu que a Restauração inaugurara os tempos bobos. Nessa época, houve um período de pacificação política na Espanha que o autor definiu como "paz boba e medíocre”. Unamuno se queixava do marasmo. Mas durante o período da Restauração modernizadora, a classe operária, ligada ao processo de industrialização recentemente iniciado, começou a manifestar-se através de organizações anarquistas e socialistas.

A questão social veio à tona e o governante Canovas se referia a ela como “a enorme questão do proletariado”. Em 1868 já atuava na Espanha a I Internacional, em 1879 foi fundado o Partido Socialista e em 1888 foi fundada a CGT; dois anos depois, o $1^{\underline{0}}$ de maio já se manifestava como um grande acontecimento, e as greves começaram a se 
suceder. Sobre o $1^{\circ}$ de maio de 1895, Galdós afirmou: "Estamos sobre um vulcão, ou seja, estamos sobre o $1^{\circ}$ de maio, dia tremendo, no qual a greve universal dos operários há de colocar no terreno prático o problema mais grave do século: a questão social, a luta entre o capital e o trabalho ${ }^{17}$."

Os intelectuais de 98 eram bem jovens nesse período de desenvolvimento capitalista intenso e de surgimento do socialismo. Maeztu escrevera sobre o capitalismo basco e se declarara socialista. Azorin era simpatizante do anarquismo. Unamuno, em 1891, já dono da cátedra de grego na Universidade de Salamanca, ainda se identificava com o socialismo e continuava escrevendo no jornal La lucha de clases de Bilbao.

Esses autores, que se manifestavam amiúde através da imprensa, assistiam com entusiasmo aos conflitos sociais do País Basco e da Catalunha.

Por ocasião da episódio de Cuba, os anarquistas e socialistas se manifestaram contra a guerra e denunciaram a injustiça em torno do serviço militar obrigatório que só penalizava os pobres. Os jovens intelectuais também fizeram críticas radicais ao sistema colonial espanhol. Maeztu, ainda que manifestasse um certo sentimento patriótico em 1898, ante a intervenção yankee na guerra, escreveu muitas páginas condenando o envio de gente do povo para lutar em Cuba. Unamuno criticou fortemente o vão patriotismo e defendeu o direito de independência dos cubanos, portorriquenhos e filipinos. Era anticolonialista e anti-racista. Discutiu o assunto da guerra em vários artigos publicados no La lucha de clases, de Bilbao.

Ao mesmo tempo que os conflitos sociais foram crescendo, sobretudo nas regiões mais industrializadas como Catalunha e País Basco, nelas também começaram a ocorrer movimentos nacionalistas periféricos que se insurgiam contra o poder central. O quadro espanhol mostrava-se bastante complicado no início do século XX.

Carlos Blanco Aguinaga, referindo-se à geração de 98, comenta que, a partir do início do século XX, vários de seus membros derivaram para um pessimismo vital que foi se acentuando ao longo dos anos. Baroja, Azorín e Maeztu foram assumindo posições políticas cada mais 
reacionárias. ${ }^{18} E$ muito provável que a derrota da Espanha na guerra tenha tido um impacto negativo sobre esses homens.

Comentando o pessimismo cada vez mais acentuado de Pio Baroja, Antonio Elorza associa essa postura ao impacto do "Desastre". ${ }^{19} \mathrm{~A}$ evolução ideológica da "geração de 98" era impressionante. Quase todos, exceto o poeta Antonio Machado e Valle Inclan, aliás os que menos se envolveram com a política e mais se dedicaram à questão estética, abandonaram suas primeiras idéias. Vários apoiaram direta ou indiretamente o franquismo.

Azorín criticava Unamuno por não ter mais fé no socialismo. Ele e Baroja faziam manifestações explosivas na imprensa contra militares, políticos e curas.

Baroja teve ambições políticas. Candidatou-se a cargos públicos mas não foi bem-sucedido, e por isso passou a ser contra a atividade política. Azorín, que criticara Unamuno pela sua falta de firmeza no apoio ao socialismo, foi deputado pelo Partido Conservador e ministro da Instrução Pública em governos conservadores; apoiou o republicanismo durante a $2^{\mathrm{a}}$ República, mas acabou se arrependendo. Tornou-se conservador e chegou a elogiar Franco.

A mudança política de Masztu foi mais radical. Ao aceitar ser embaixador de Primo de Rivera na Argentina, abjurou seu livro Hacia outra España, escrito em 1899. Passou a teorizar sobre a hispanidad numa perspectiva católica e imperial. Com o advento da $2^{\underline{a}}$ República, certa vez comentou o seguinte sobre esse livro que escrevera: "Todas as suas páginas merecem ser queimadas, mas o título expressa o ideal de 98 e o de agora.” A “outra Espanha” era a da Ação Católica ou a da Renovação espanhola? -indaga Federico Alvarez, autor do texto Evolução política da geração de 98.

Com o desenrolar dos acontecimentos políticos na Espanha, Maeztu tornou-se ideólogo da extrema direita. De socialista, crítico do capitalismo, acabou como um dos fundadores do partido de extrema direita "Renovação espanhola", e teceu loas ao franquismo. Ortega y Gasset havia dedicado à obra Meditaciones de Quijote (1914) a Maeztu, mas eliminou a dedicatória na segunda edição porque o companheiro pas- 
sara de armas e bagagens para o campo da monarquia e da ditadura de Primo de Rivera. Quando foi a Buenos Aires, Ortega mandou pedir que o embaixador Maeztu não fosse assistir à sua conferência - conta melancolicamente o próprio Maeztu. ${ }^{20}$

Unamuno, cabe lembrar, viveu uma crise espiritual que o direcionou para a metafísica. Mas não deixou de manifestar-se e tomar partido diante da política nacional. Foi contra a ditadura de Primo de Rivera e, por isso, sofreu prisão e exílio por 7 anos; voltou com honras e glórias, mas não se sabe se voltou republicano. Em 1931, já na posição de reitor de Salamanca, atacou os republicanos e elogiou o regime da Restauração. Encontrou-se com Primo de Rivera e assistiu a uma manifestação da Falange. O triunfo eleitoral da Frente Popular em 1936 já fazia vislumbrar o espectro da guerra; em 18 de julho deu-se a sublevação do exército contra o poder legítimo da República: Unamuno se juntou publicamente aos militares sublevados e aceitou ser conselheiro da Câmara Municipal salmantina. Além de calar-se ante o assassinato de um amigo e colega, presidiu o comitê depurador de professores e intelectuais da Província. Justificou a sublevação "para defender nossa civilização cristã ocidental que formou a Europa, contra a ideologia oriental destrutora”.

Logo depois, foi destituído do cargo de reitor e submetido a prisão domiciliar. Morreu em dezembro de 1936. Nos últimos dias de sua vida repudiou o franquismo.

Valle Inclan, ao contrário, partiu do carlismo mas acabou se encantando com os revolucionários mexicanos e russos. Na Espanha, identificou-se com a República e com a Frente Popular. Antonio Machado, formado num ambiente liberal laico, não manifestava interesse pela política mas, no final, assumiu compromisso com a Frente Popular durante a Guerra Civil. ${ }^{21}$

Como explicar tantas transformações? Cabe lembrar que nesse ínterim os conflitos sociais e políticos se aguçaram na Espanha. Nas mesmas regiões onde o socialismo ganhava terreno, fizeram também 
violenta irrupção os autonomistas catalãos, bascos e galegos. As greves se sucediam nessas localidades, e em 1917 ocorreu a greve geral com duração de uma semana. A repressão resultou em 80 mortos, 150 feridos e 2.000 detidos. A influência da Revolução Russa entusiasmava a classe operária e seus líderes. Nas manifestações de apoio aos grevistas presos ouviam-se os "Vivas à Rússia". Enquanto isso os defensores e simpatizantes da ordem se apavoravam.

Com o advento da República, alguns representantes de 98 se uniram em torno dela. Mas quando os partidos de esquerda se situaram no comando do movimento republicano, houve reação dos intelectuais. Baroja passou a escrever impropérios contra a República. Logo depois, Unamuno fez o mesmo. Depois de um alarde antifranquista, respaldou, em 1936, a sublevação militar e depois se arrependeu. Nas várias fases de sua vida, caracterizou-se pelo pessimismo. ${ }^{22}$

Aliás, o pessimismo foi uma das principais características da geração de 98. Na juventude eram pessimistas em relação ao statu quo e, posteriormente, quanto a qualquer possibilidade de mudança significativa. Acabaram marcados pelo ceticismo teórico e vital. Cabe aqui lembrar, citando William James, que o pessimismo é essencialmente uma enfermidade religiosa porque implica uma exigência absoluta e integral de sentido que nunca encontra nenhuma resposta satisfatória. O resultado do pessimismo consistiu, como observa Galán, numa sedução tanática pelo nada. Como na Espanha, às vésperas da Guerra Civil, não havia espaço para o nada, vários intelectuais da "geração de 98" acabaram navegando para a outra margem do rio, a margem direita onde melancolicamente terminaram seus dias, contemplando o vazio da existência ou lutando do outro lado da trincheira, como foi o caso de Maeztu. Este autor sugeriu que seus escritos poderiam ser queimados. Não foi o único na história a renegar o que escreveu. Mas os intelectuais não renegam seus escritos impunemente, pois a história acaba por resgatá-los.

CAPELATO, M.H. The 1898's symbol date: the Cuban Independence impact in Spain and Spanish America. História. São Paulo, v. 22, n. 2, pp. 35-58, 2003. 
A B S TRACT: The article aims to analyze the Cuban Independence impact in Spanish and Spanish American intellectuals and the approximation reasons between them after the event. 1898 became a symbol date through the significatives changes that produced in Spanish American writers about the United State's role in Latin America and about the Spain's destiny after the loss of the last Spanish colony in America.

KEYWORDS: intellectual History; "hispanity"; Cuban independence.

\section{NOTAS}

${ }^{1} \mathrm{O}$ texto foi apresentado como conferência no V Encontro da ANPHLAC (Associação Nacional de Pesquisadores de História Latino-Americana e Caribenha), realizado na UFMG, Belo Horizonte, em julho de 2002.

${ }^{2}$ Departamento de História - FFLCH - USP - CEP 05508-900 - São Paulo - SP.

${ }^{3}$ BLANCO AGUINAGA, C. Los escritores del 98 hace cien años: lucha de clases y guerra colonial. In: ZEA, L. \& MIAJA, M. T. (Comp.). 98: Derrota Pírrica. México: IPGH e Fondo de Cultura Económica, 2000, pp.141-160.

${ }^{4}$ VARELA, J. Introducción. In: MAEZTU, R. de. Hacia otra Espanã. Madrid: Editorial Biblioteca Nueva, 1997, pp.21- 22.

${ }^{5}$ ROYANO, L. (Ed.). Fuera del Olvido: los escritores hispanoamericanos frente a 1898. Santander: Universidad de Cantabria, 2000, p. 8.

${ }^{6}$ PINEDO, J. Ser outro sin dejar de ser uno mismo: España, identidad y modernidad en la generación del 98 . In: ZEA, L. \& SANTANA, A. (Comp.). El 98 y su impacto en Latinoamérica. México: IPGH e Fondo de cultura Económica, 2001, pp. 77-106.

${ }^{7}$ CEREZO GALÁN, P. La doble crisis, ideologica e intelectual, del 98. In: ZEA, L. \& MIAJA, M. T. (Comp.). Op. cit., pp. 93-116.

${ }^{8}$ SÁNCHEZ VÁZQUEZ, A. Los de 98 y la política. In: ZEA, L. \& MIAJA, M. T. (Comp.). Op. cit., pp. 31-42.

${ }^{9}$ RIBAS, P. La generación del 98: consideraciones críticas. In: ZEA, L. \& MIAJA, M. T. (Comp.). Op. cit., pp. 171-182.

${ }^{10}$ FERNANDÉZ, T. España y la cultura hispanoamericana tras el 98. In: ROYANO, L. (Ed.). Op. cit., pp. 11-32.

${ }^{11}$ DEVÉS, E. El pensamiento latino-americano entre la última orilla del siglo XIX y la primera del siglo XXI. In: ZEA, L. \& SANTANA, A. (Comp.). Op. cit., p. 23. 
${ }^{12}$ Idem, p. 31.

${ }^{13}$ FERNANDÉZ, T. Op. cit., p. 19.

${ }^{14}$ Idem.

${ }^{15}$ Idem.

${ }^{16}$ DEVÉS, E. Op. cit., p. 33.

${ }^{17}$ BLANCO AGUINAGA, C. Op. cit., p. 148.

${ }^{18}$ Idem, p. 159.

${ }^{19}$ ELORZA, A. Los noventayochos y la crisis del Estado-nación. In: ZEA, L. \& MIAJA, M. T. (Comp.). Op. cit., p. 76.

${ }^{20}$ ÁLVARES, F. Evollución politica de la generación del 98. In: ZEA, L. \& MIAJA, M. T. (Comp.). Op. cit., p. 49.

${ }^{21}$ SÁNCHEZ VÁZQUEZ, A. Op. cit., pp. 31-42.

${ }^{22}$ ÁLVARES, F. Op. cit.

Artigo recebido em 06/2003. Aprovado em 09/2003. 